\title{
Research on the Influence of Online Video Bullet-screen Advertising Marketing on Consumers' Purchasing Intention
}

\author{
Gao-fu LIU \\ Business school of Jiangxi Normal University \\ Nanchang, China \\ Hui-ming XU \\ Business school of Jiangxi Normal University \\ Nanchang, China
}

\author{
Le-lin LI* \\ Business school of Jiangxi Normal University \\ Nanchang, China \\ Meng-qiu LUO \\ Business school of Jiangxi Normal University \\ Nanchang, China
}

\begin{abstract}
With the development of science and technology, the world has entered a new information age. The novel marketing method of network advertising makes traditional advertising more and more marginalized. Bullet screen advertising undoubtedly makes this Internet age a representative advertising marketing model. It has the characteristics of wide advertising coverage, strong pertinence, good concealment and considerable effect. This paper takes video apps of various online bullet screens as research objects to study the influence of launching bullet screen advertisements on the online video platform on audience buying intention. This paper mainly analyzes the factors influencing consumers' acceptance of brand in bullet screen advertising, and establishes the relationship model of three dimensions of bullet screen advertising marketing, consumers' brand attitude and consumers' purchase intention by combining with the characteristics of screen video advertising and by studying specific objects. This paper collects data through questionnaire survey and conducts data analysis with SPSS to test the relationship between variables. Through empirical research, it is proved that whether the text content style, launch time and correlation degree of video content emotion of bullet screen advertisements have positive effects on consumers' purchase intention. This paper provides an effective reference value for enterprises to open up new advertising marketing channels and provides suggestions for their subsequent development.
\end{abstract}

Keywords-Network Video Platform, Bullet-Screen Advertising; Brand Attitude; Purchase Intention

\section{INTRODUCTION}

With the rapid development of the Internet, the development of online advertising and new media has brought a great impact on traditional advertising, while the traditional TV, outdoor, poster style hard wide is gradually tired by the public.

The existing Internet environment has spawned a real-time interactive comment mode called "bullet screen", which is more popular among young netizens. As a medium, bullet screen provides a brand new advertising marketing method for enterprises and brands. Through soft promotion, it can be better accepted by the public. Therefore, appropriate barrage advertisements have no contradiction and can "seamlessly contact" with barrage audiences psychologically. However, when enterprises and advertisers choose to use bullet-screen advertising, there are some problems, such as improper language and visual expression, imprecise timing, and rigid placement of bullet-screen advertisements, which result in consumers' dislike and other consequences. In the online video bullet-screen advertising marketing, in order to achieve the wide coverage of advertising and good brand communication effect, it is necessary to understand what factors the audience is affected by when watching video on the Internet and what habits and hobbies they have. Therefore, the main research question of this study is to analyze the factors that ultimately affect consumers' purchase intention from the relationship between the characteristics of certain elements of bullet-screen advertising and consumers' brand attitudes.

The theoretical and practical significance of this paper is mainly reflected in the following two aspects: 1) Theoretical significance: this study analyzes the factors that affect the marketing effect of barrage advertising by using the three dimensions selected to influence consumers' brand attitude and thus their purchase intention, which is to put the theory into practice. 2) Practical significance: this paper studies the impact of video barrage advertising marketing on consumers' purchase intention from the perspective of consumers' brand attitude, in addition to improving the public's cognition of video barrage advertising.

\section{LITERATURE REVIEW}

\section{A. Research on bullet-screen advertising marketing}

In the existing literature and relevant research, the term of "bullet screen advertising" has not been defined clearly. Combined with the characteristics of "bullet screen" and "advertisement", we can roughly make a simple exposition of bullet screen advertising: "barrage advertising" refers to the existing internet platform under the social development, enterprise want to make the target consumer to strengthen its corporate brand, brand image and product service of cognitive, 
and choose to send in the form of barrage advertising information relating to the product or obscure include product information, in order to deepen the consumer impression of their products, thereby to guide the consumer, influence consumer purchase intention [1].

The concept of text content style is a concept that emerged in the related research of Shan WANG and others. Enterprise product marketing is based on the bullet screen itself as the carrier of the advertisement "copywriting", which mainly refers to the video of product promotion and promotion by means of the barrage. The barrage advertisement must be published in accordance with the language characteristics of the "bow-screen family" who love to vomit and create various online buzzwords [2]. This group has obvious "sub-culture" characteristics and has strong entertainment in language style. They created a kind of "group carnival" atmosphere in a video bombing that "spits into the wind".

In the aspect of product episodic advertising marketing, just as news communication and public opinion persuasion need to be clear about the target audience, one of the key points of marketing promotion is to be clear about the target consumer group. Because most brands also have the corresponding "age" and "gender", that is, some products are suitable for young people, some are suitable for the elderly, and different products are naturally applicable to different genders [3]. In general, differences in age and gender will lead to different perspectives of people's attention to various products. Consumers usually only pay attention to the advertising information of the products related to themselves, so targeted and precise marketing produces publicity effect.

The more relevant video content is, the more likely the audience is to accept the product. Advertising barrage that conforms to the "context" of the plot or makes fun of the profound ability is usually regarded as "well-intentioned" barrage, which disguises its marketing intention with the entertainment of its language and makes the audience unconsciously influenced by the propaganda information [4].

\section{B. Research on consumer brand attitude}

Brand attitude mainly exists in the memory of consumers and plays a major role in their purchasing behavior. Product characteristics, personal habits and preferences also play an important role in shaping brand attitudes.

As for the definition of consumer brand attitude, scholars have different theoretical views in different periods: Fishbein and Ajzen (1975) defined consumer brand attitude as consumers' preference or aversion to a brand. Westbrook and Percy and Rossiter (1992) believed that it was a comprehensive evaluation of a brand's ability to meet its own needs and goals. Xiao-hong $\mathrm{HU}(2009)$ pointed out that the so-called consumer brand attitude is the overall evaluation of a brand by consumers, which depends on the performance of consumers' relevant knowledge of a brand.

\section{Research on consumers' purchase intention}

Just as Aaker and other scholars have said, consumers' purchase intention is the basis of the purchase decision. To accurately predict consumers' actual purchase behavior, it is necessary to deeply study consumers' purchase intention. As for the definition of consumers' purchase intention, different scholars have different opinions from different perspectives.

- Fishbein and Ajze (1975) defined the purchase intention of consumers as the possibility of consumers' active purchase behavior.td.

- Mullet and Karson (1985) defined the purchase intention of consumers as consumers' preference for brands or products, which can be the subjective probability of consumers' purchase behavior through external factors.

- Eagly and Chaiken (1993) defined the purchase intention of consumers as a measure of the possibility of consumers to buy a certain product or service.

- Jian-ying FENG (2006) defined the purchase intention of consumers as the possibility of consumers' active purchase behavior.

\section{RESEARCH MODEL AND RESEARCH HYPOTHESIS}

Based on the summary and review of previous literature and research issues, the conceptual model of this paper is proposed, as shown in Fig. 1:

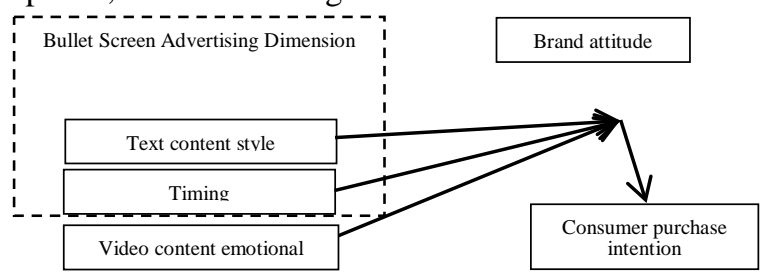

Fig. 1. Research model

\section{THE HYPOTHESIS OF RELATIONSHIP BETWEEN BULLET SCREEN ADVERTISING AND CONSUMER BRAND ATTITUDE}

\section{A. Relationship between content style and brand attitude}

The popularity of barrage video has a lot to do with the popularity of a large number of young netizens. If companies choose to play bar-screen ads in online videos, they must consider the needs of such audiences, and use their familiar and loved bullets [5]. Converting the advertising copy to be released, making it humorous and witty "self-deprecating" language and visual expression, thus bringing the distance to the audience closer, so that the product information contained in the barrage advertisement can be left in the mind of the target consumer [6]. Positive image deepens the audience's impression of the brand, and thus have positive brand awareness and brand attitude. On the contrary, if the advertisement commercial sturdy advertising copy style is incompatible with the style of the barrage, the audience's spit and resentment will greatly reduce its marketing effect. Therefore this study assumes:

H1: text content style will positively influence the brand attitude of the audience.

\section{B. The relationship between launch time and brand attitude}

It's important to pick and place a barrage ad. In the "golden section" or video story will enter the climax of the barrage advertising and bring greater exposure to the brand, 
making the audience coverage of bullet screen advertisement wider [7]. This not only accurately targets the target population, but also effectively improves the arrival rate of advertising, advertising display and dissemination effects are relatively good. On the contrary, if we do not consider the feelings of the audience and do not choose the right time to release hard wide, it will cause consumers' aversion to the product or the brand. Therefore, the hypothesis of this study is:

H2: the launch opportunity positively affects the brand attitude of the audience

\section{Bullet screen advertising and video content emotional correlation and brand attitude}

High relevance is the basis for the good communication effect of advertising, and it is the most effective way to maximize the interests of both advertisers and video platforms; low relevance will inevitably lead to resentment of the audience [8]. At this time, the audience will transfer this resentment to the brand. Up, thus creating a bad impression on the brand, which in turn affects the brand's image, and at the same time has a negative impact on the viewing effect [9]. Therefore this study assumes that:

H3: the association between bullet screen advertisements and video content emotions will positively affect the brand attitude of the audience

\section{Hypothesis on the relationship between brand attitude and consumers' purchase intention}

Many existing research results show that brand attitude has a significant impact on consumers' purchase intention and behavior. In real life, enterprises also hope that the audience's attitude towards the products or services represented by the advertisements in barrage video will be transferred to the real products or services, and the existing brand attitude will be used to stimulate the purchase behavior when facing the purchase decision [10]. For this research hypothesis:

H4: video audience's attitudes towards product brands positively affect their purchase intentions.

\section{RESEARCH DESIGN AND EMPIRICAL ANALYSIS}

\section{A. Variable definitions}

According to the analysis above, there are five variables in this paper, which are respectively: text content style, timing, emotional relevance to video content, consumer brand attitude and consumer purchase intention. The specific definition of each variable is as follows.

- Text content style: it mainly refers to video barrage advertisements that use barrage to promote products. The release of the ads must conform to the language characteristics of the "barrage clan" group that loves teasing and making all kinds of network buzzwords [11]. Based on the above statement, this study defines the style of text content as: the richness of the language and expression of the video-screen advertising and the degree of entertainment.

- Timing: when launching a barrage advertisement, enterprises should find the right time and accurately deliver it. When the barrage advertisement is released, it can not only display the product information but also enhance the real-time interaction with the audience, because the barrage interaction can bring the netizens back to reality and trigger the netizens.

- Emotional relevance to video content: when choosing a product with bullet screen advertising to be associated with video content, the higher the correlation, the more likely the audience is to accept the product [12]. Advertising barrage that conforms to the "context" of the plot or makes fun of the profound ability is usually regarded as "well-intentioned" barrage, which disguises its marketing intention with the entertainment of its language and makes the audience unconsciously influenced by the propaganda information.

- Consumer brand attitude: consumers form their own subjective evaluation on the impression of the brand and generate their purchase intention of the brand products or services. Brand attitude mainly exists in the memory of consumers and plays a major role in their purchasing behavior.

- Consumer purchase intention: The purchase intention of consumers is mainly composed of consumers' attitude towards the brand and some external factors. The purchase intention is the subjective tendency of consumers and can be proved as a pre-variable of consumption behavior. And consumer intention is defined in this paper as the probability that consumers are willing to buy a certain product or service.

\section{B. Research design}

In this study, the variables to be measured are divided into three categories: exogenous variables, mediating variables, and endogenous variables. Among them, external variables include text content style, launch time, and video content emotional correlation degree. The intermediary variable is the brand attitude of consumers. The endogenous variable is the purchase intention of consumers. The Likert five-point rating scale proposed by Likert scholars was used to measure the variables. First, through literature review and communication with others to get the questionnaire questions; secondly, analyze the reliability and validity of the scale, adjust and improve the questions. Then a formal questionnaire was conducted; finally, the collected data are collated and analyzed for quantitative research.

\section{Sample characteristics}

TABLE I. SAMPLE STRUCTURE DESCRIPTION

\begin{tabular}{|c|c|c|c|}
\hline Basic situation & Options & Number & Proportion \\
\hline \multirow{2}{*}{ Gender } & Male & 33 & $22.6 \%$ \\
\cline { 2 - 4 } & Female & 113 & $77.4 \%$ \\
\hline \multirow{4}{*}{ Age } & $<\mathbf{1 8 ,}$ & 3 & $2.05 \%$ \\
\cline { 2 - 4 } & $\mathbf{1 8} \sim \mathbf{2 2}$ & 79 & $54.11 \%$ \\
\cline { 2 - 4 } & $\mathbf{2 3} \sim \mathbf{2 8}$ & 33 & $22.6 \%$ \\
\cline { 2 - 4 } & $\mathbf{2 9} \sim \mathbf{3 5}$ & 24 & $16.44 \%$ \\
\cline { 2 - 4 } & $\mathbf{3 6} \sim \mathbf{4 5}$ & 6 & $4.11 \%$ \\
\cline { 2 - 4 } & $\mathbf{> 4 6}$ & 1 & $0.68 \%$ \\
\hline
\end{tabular}




\begin{tabular}{|c|c|c|c|}
\hline \multicolumn{4}{|l|}{ Cont. to TABLE I. } \\
\hline \multirow{4}{*}{$\begin{array}{c}\text { Income } \\
\text { [yuan] }\end{array}$} & $\mathbf{2 0 0 0}$ & 72 & $49.32 \%$ \\
\cline { 2 - 4 } & $\mathbf{2 0 0 0 - 6 0 0 0}$ & 56 & $38.36 \%$ \\
\cline { 2 - 4 } & $\mathbf{6 0 0 0 - 9 0 0 0}$ & 13 & $8.9 \%$ \\
\cline { 2 - 4 } & $\mathbf{9 0 0 0}$ & 5 & $3.42 \%$ \\
\hline \multirow{4}{*}{$\begin{array}{c}\text { Number of times to use the barrage } \\
\text { video }\end{array}$} & $\begin{array}{c}\text { Every day } \\
\text { to } 2 \text { times a } \\
\text { week }\end{array}$ & 26 & $58.9 \%$ \\
\cline { 2 - 4 } & $\begin{array}{c}\text { 3 to 4 times a } \\
\text { week }\end{array}$ & 19 & $14.38 \%$ \\
\cline { 2 - 4 } & More than a week & 15 & $10.27 \%$ \\
\cline { 2 - 4 } & Occasionally used & 5 & $3.42 \%$ \\
\hline
\end{tabular}

In this survey, 146 questionnaires were collected, all of which were valid. SPSS25.0 was used to analyze these data. In the collected questionnaires, the basic information of male and female ratio of consumers, age distribution, monthly living expenses and times of using barrage video are shown in TABLE I.

\section{The reliability analysis}

In this study, Cronbach's Alpha coefficient will be used to test the reliability of the questionnaire. The higher the alpha value, the higher the reliability of the questionnaire, and vice versa. This paper uses SPSS24.0 to conduct reliability analysis, and the analysis results are shown in TABLE II:

TABLE II. RELIABILITY ANALYSIS OF EACH RESEARCH VARIABLE

\begin{tabular}{|c|c|c|c|}
\hline $\begin{array}{c}\text { The research } \\
\text { variables }\end{array}$ & $\begin{array}{c}\text { Number of } \\
\text { questions }\end{array}$ & $\begin{array}{c}\text { Cronbach's } \\
\text { Alpha }\end{array}$ & $\begin{array}{c}\text { The reference } \\
\text { standard }\end{array}$ \\
\hline Overall variables & 20 & 0.898 & \multirow{2}{*}{$\alpha \geq 0.60$} \\
\hline Text content style & 4 & 0.821 & \\
\hline Timing & 4 & 0.798 & \\
\hline $\begin{array}{c}\text { Emotional } \\
\text { relevance to video } \\
\text { content }\end{array}$ & 4 & 0.834 & \\
\hline $\begin{array}{c}\text { Consumer brand } \\
\text { attitude }\end{array}$ & 4 & 0.819 & \\
\hline $\begin{array}{c}\text { Consumer purchase } \\
\text { intention }\end{array}$ & 4 & 0.822 & \\
\hline
\end{tabular}

In practice, as long as the alpha value reaches 0.60 , the reliability of the measurement is acceptable. Therefore, the reliability standard set in this study is alpha $\geq 0.60$, that is, as long as the alpha value of this study is greater than 0.6 , it indicates that the reliability of this scale is valid. As can be seen from the above table, the overall alpha value of the questionnaire is 0.898 , indicating that the scale used in the questionnaire has high reliability and good reliability, and the alpha value of all variables is above 0.6 . That is to say, all the alpha coefficients were in line with the standards set in this study, indicating that the questionnaire was effective.

\section{E. Validity analysis}

TABLE III. VALIDITY TEST OF EACH RESEARCH VARIABLE

\begin{tabular}{|c|c|c|c|c|}
\hline The research variables & $\begin{array}{c}\text { Measurement } \\
\text { question }\end{array}$ & $\begin{array}{c}\text { Factor } \\
\text { load }\end{array}$ & KMO & $\begin{array}{c}\text { Bartlett test } \\
\text { significance }\end{array}$ \\
\hline \multirow{3}{*}{ Text content style(A) } & $\mathbf{A 1}$ & 0.741 & & \multirow{2}{*}{0.000} \\
\cline { 2 - 3 } & $\mathbf{A 2}$ & 0.763 & \multirow{2}{*}{0.765} & \multirow{2}{*}{0.000} \\
\cline { 2 - 3 } & $\mathbf{A 3}$ & 0.798 & & \\
\cline { 2 - 3 } & $\mathbf{A 4}$ & 0.688 & & \\
\hline
\end{tabular}

\begin{tabular}{|c|c|c|c|c|}
\hline \multicolumn{5}{|c|}{ Cont. to TABLE II. } \\
\hline \multirow{4}{*}{ Timing(B) } & B1 & 0.654 & \multirow{4}{*}{0.771} & \multirow{4}{*}{0.000} \\
\hline & B2 & 0.744 & & \\
\hline & B3 & 0.802 & & \\
\hline & B4 & 0.743 & & \\
\hline \multirow{4}{*}{$\begin{array}{c}\text { Emotional relevance to } \\
\text { video content } ₫\end{array}$} & C1 & 0.853 & \multirow{4}{*}{0.761} & \multirow{4}{*}{0.000} \\
\hline & C2 & 0.756 & & \\
\hline & C3 & 0.731 & & \\
\hline & C4 & 0.615 & & \\
\hline \multirow{4}{*}{$\begin{array}{l}\text { Consumer brand } \\
\text { attitude(D) }\end{array}$} & D1 & 0.607 & \multirow{4}{*}{0.806} & \multirow{4}{*}{0.000} \\
\hline & D2 & 0.603 & & \\
\hline & D3 & 0.813 & & \\
\hline & D4 & 0.591 & & \\
\hline \multirow{4}{*}{$\begin{array}{l}\text { Consumer purchase } \\
\text { intention }(E)\end{array}$} & E1 & 0.774 & \multirow{4}{*}{0.781} & \multirow{4}{*}{0.000} \\
\hline & $E 2$ & 0.719 & & \\
\hline & E3 & 0.532 & & \\
\hline & E4 & 0.586 & & \\
\hline
\end{tabular}

Validity refers to validity, which means that the measuring tool can accurately measure the characteristics to be measured. In general, when the $\mathrm{KMO}$ value is lower than 0.6, it is not suitable for factor analysis. In this paper, as can be seen from the following table, the KMO values of questions $\mathrm{A}, \mathrm{B}, \mathrm{C}, \mathrm{D}$ and $\mathrm{E}$ are all above 0.7 , indicating that there is no significant difference in the degree of correlation between questions in the same scale. The significance level of Bartlett test is 0.000 , indicating that there is correlation among the items. In addition, it is generally believed that the questionnaire is considered effective when the factor load is greater than 0.4. In TABLE III, the factor loads of all questions are greater than 0.4. Therefore, the questionnaire items in this study are all valid.

\section{HYPOTHESIS TESTING}

\section{A. Correlation analysis}

In this study, the person correlation coefficient in bivariate was used for analysis, the correlation analysis of this paper is shown in TABLE IV below. The data results show that there are significant correlations between the three dimensions of the curtain-type advertising marketing and the consumer brand attitude, indicating that curtain-type advertising marketing can influence the consumer brand attitude.

TABLE IV. CORRELATION ANALYSIS BETWEEN VARIABLES

\begin{tabular}{|c|c|c|c|c|c|c|}
\hline Variable & & 1 & 2 & 3 & 4 & 5 \\
\hline \multirow{3}{*}{ Text content style } & $\begin{array}{c}\text { Person } \\
\text { (relevance) }\end{array}$ & 1 & $0.518^{*}$ & 0.198 & $0.528 * *$ & 0.465 \\
\hline & $\begin{array}{l}\text { Significant } \\
\text { (two-tailed) }\end{array}$ & & 0.046 & 0.068 & 0.009 & 0.014 \\
\hline & $N$ & 146 & 146 & 146 & 146 & 146 \\
\hline \multirow{3}{*}{ Timing } & $\begin{array}{c}\text { Person } \\
\text { (relevance) }\end{array}$ & $0.548 *$ & 1 & $0.259 * *$ & $0.423 *$ & 0.223 \\
\hline & $\begin{array}{l}\text { Significant } \\
\text { (two-tailed) }\end{array}$ & 0.046 & & 0.001 & 0.034 & 0.122 \\
\hline & $N$ & 146 & 146 & 146 & 146 & 146 \\
\hline \multirow{3}{*}{$\begin{array}{c}\text { Emotional } \\
\text { relevance to video } \\
\text { content }\end{array}$} & $\begin{array}{c}\text { Person } \\
\text { (relevance) }\end{array}$ & 0.199 & $0.258 * *$ & 1 & $0.632 * *$ & $0.525 * *$ \\
\hline & $\begin{array}{l}\text { Significant } \\
\text { (two-tailed) }\end{array}$ & 0.067 & 0.001 & & .019 & 0.005 \\
\hline & $N$ & 146 & 146 & 146 & 146 & 146 \\
\hline
\end{tabular}




\begin{tabular}{|c|c|c|c|c|c|c|}
\hline \multicolumn{7}{|c|}{ Cont. to TABLE IV. } \\
\hline \multirow{4}{*}{$\begin{array}{c}\text { Consumer brand } \\
\text { attitude }\end{array}$} & $\begin{array}{c}\text { Person } \\
\text { (relevance) }\end{array}$ & $0.485 *$ & $0.496 *$ & $0.612 * *$ & 1 & $0.392 *$ \\
\cline { 2 - 8 } & $\begin{array}{c}\text { Significant } \\
\text { (two-tailed) }\end{array}$ & 0.006 & 0.024 & 0.006 & 0.008 & 0.018 \\
\cline { 2 - 8 } & $\boldsymbol{N}$ & 146 & 146 & 146 & 146 & 146 \\
\hline \multirow{3}{*}{$\begin{array}{c}\text { Consumer purchase } \\
\text { intention }\end{array}$} & $\begin{array}{c}\text { Person } \\
\text { (relevance) }\end{array}$ & $0.463 * *$ & $0.222 * *$ & $0.525 * *$ & $0.485 * *$ & 1 \\
\cline { 2 - 7 } & $\begin{array}{c}\text { Significant } \\
\text { (two-tailed) }\end{array}$ & 0.004 & 0.121 & 0.005 & 0.006 & \\
\cline { 2 - 7 } & $\boldsymbol{N}$ & 146 & 146 & 146 & 146 & 146 \\
\hline
\end{tabular}

**Significant correlation at the 0.01 level (both sides). *.Significantly correlated at 0.05 level (two

\section{B. Regression Analysis of Video Barrage Advertising Marketing and Consumer Brand Attitude}

The regression analysis data of consumer brand attitudes in this study are shown in TABLE V:

TABLE V. REGRESSION ANALYSIS OF CONSUMER BRAND ATTITUDE

\begin{tabular}{|c|c|c|c|c|c|}
\hline \multirow{2}{*}{ Model } & \multicolumn{2}{|c|}{$\begin{array}{c}\text { Non-standardized } \\
\text { coefficient }\end{array}$} & $\begin{array}{c}\text { Standardization } \\
\text { coefficient }\end{array}$ & $\begin{array}{c}\text { T } \\
\text { test }\end{array}$ & $\begin{array}{c}\text { Significant } \\
\text { level }\end{array}$ \\
\cline { 2 - 6 } & $\boldsymbol{B}$ & $\begin{array}{c}\text { Standard } \\
\text { deviation }\end{array}$ & $\boldsymbol{\beta}$ & $\boldsymbol{T}$ & Sig \\
\hline Constant & 0.637 & 0.111 & & 4.032 & 0.000 \\
\hline $\begin{array}{c}\text { Text } \\
\text { content } \\
\text { style (A) }\end{array}$ & 0.445 & 0.087 & 0.458 & 6.847 & 0.000 \\
\hline $\begin{array}{c}\text { Timing } \\
\text { (B) }\end{array}$ & 0.354 & 0.064 & 0.326 & 8.598 & 0.000 \\
\hline $\begin{array}{c}\text { Emotional } \\
\text { relevance } \\
\text { to video } \\
\text { content } \\
\text { (C) }\end{array}$ & 0.373 & 0.079 & 0.371 & 4.279 & 0.000 \\
\hline
\end{tabular}

As can be seen from the above table, the $B$ value of the three variables are all positive, and the significance level of $\mathrm{T}$ value is 0.000 , less than 0.01 . So, there is a significant causal relationship between the three dimensions of independent variable and brand attitude, and its coefficients are all positive, so it is a positive correlation. The equation of consumer brand attitude is: $\mathrm{M}=0.445 \mathrm{~A}+0.354 \mathrm{~B}+0.373 \mathrm{C}+0.637$, and the degree of their influence on consumer brand attitude is ranked from strong to weak: $\mathrm{A}>\mathrm{C}>\mathrm{B}$. Therefore, hypothesis $\mathrm{H} 1, \mathrm{H} 2$ and $\mathrm{H} 3$ are valid.

\section{Regression analysis of consumer purchase intention}

There is a significant causal relationship between factor $\mathrm{M}$ and consumer purchase intention, and the coefficient is positive, so it is a positive correlation. Therefore, the expression of consumers' purchase intention is $\mathrm{Y}=0.594 \mathrm{M}+0.228$. So let's say that $\mathrm{H} 4$ is true.

TABLE VI. REGRESSION ANALYSIS OF CONSUMERS' PURCHASE INTENTION

\begin{tabular}{|c|c|c|c|c|c|}
\hline \multirow{2}{*}{ Model } & \multicolumn{2}{|c|}{$\begin{array}{c}\text { Non-standardized } \\
\text { coefficient }\end{array}$} & $\begin{array}{c}\text { Standardization } \\
\text { coefficient }\end{array}$ & $\begin{array}{c}\mathbf{T} \\
\text { test }\end{array}$ & $\begin{array}{c}\text { Significant } \\
\text { level }\end{array}$ \\
\cline { 2 - 6 } & $\boldsymbol{B}$ & $\begin{array}{c}\text { Standard } \\
\text { deviation }\end{array}$ & $\boldsymbol{\beta}$ & $\boldsymbol{T}$ & Sig \\
\hline Constant & 0.228 & 0.142 & & 5.018 & 0.000 \\
\hline $\begin{array}{c}\text { Brand } \\
\text { attitude } \\
(\boldsymbol{M})\end{array}$ & 0.594 & 0.055 & 0.585 & 7.694 & 0.000 \\
\hline
\end{tabular}

\section{RESEARCH CONCLUSION AND DISCUSSION}

\section{A. Conclusion and suggestion}

Based on the above research results, the following conclusions and Suggestions can be drawn:

1) The text content style of video barrage ads has a positive impact on consumers' brand attitudes. Enterprises want to use the medium of the barrage to launch video barrage advertisements to enhance the impression of brands or products in the hearts of consumers. The advertisements and styles to be published must conform to this "love and spit" and have "barrage". The linguistic features of a large number of barrage groups, so that the product and video content and audience consumers can better interact and integrate, making video-screen advertising marketing have certain feasibility and can bring good communication effects.

2)The timing of video barrage advertising has a positive impact on consumer brand attitudes. When enterprises use the curtain-type advertising marketing, they must combine the consumer's viewing experience to release the barrage advertisement, and reasonably arrange the time of the barrage advertisement. Pay attention not to affect the audience's emotions, otherwise it will be resentful to the advertisement. It has the opposite effect and reduces the image of the product in the minds of consumers. The more accurate the timing of the launch, the easier it is for the consumer brand to perceive, so that consumers have a positive brand attitude towards the product.

3) The correlation between the barrage advertisement and the video content and emotion has a positive impact on the consumer brand attitude. For ads play episodic plot and content of emotions in terms of correlation, advertisers should grasp the timing of the advertising appearances, grasp the audience with the dramatic changes of mood changes, in the case of guaranteed video content plot smoothly, accurate barrage advertising, and advertising plays a significant role in video, enlarging the barrage of advertising communication effects.

4) consumers' brand attitudes have a positive impact on their purchase intentions. In the marketing process, enterprises should pay attention to consumers' feelings and experiences from the perspective of consumers. The design of barrage advertisements should fully consider the acceptance and visual experience of consumers, the frequency and manner of product information exposure, Humorous and interesting language style, and the opportunity to accurately display the barrage advertisement can enhance the consumer's impression of the product, thus laying the foundation for a good brand attitude and prompting consumers to purchase the product.

\section{B. Research innovation}

Firstly, at present, some scholars have carried out relevant researches on video barrage and barrage marketing, but the research focuses on the pattern of barrage advertising communication, and it is rare to divide barrage advertising into several dimensions for relevant researches. This research has a new division on the dimension of video barrage advertising, which is an innovation. 
Secondly, this paper selects the perspective of the influence of consumer brand attitude, constructs a conceptual model, and explores the content style of text barrage advertising, the timing and content of content, and the degree of emotional relevance to consumer brands. The influence of attitudes and brand attitudes as mediators ultimately explore how the factors of barrage advertising affect consumers' purchase intention.

\section{Research limitations}

First of all, due to the limited ability of my research, there are still many shortcomings in the choice of variables, and the three dimensions of selection are also limited, so that research cannot be carried out in depth. Secondly, in the design of the questionnaire, the problem design is not comprehensive enough, and the measurement of the variables needs to be more accurate.

\section{Research outlook}

Firstly, the variables selected in this paper are relatively simple, and we hope to find more variables related to consumers' brand attitudes and influencing their purchase intentions in the future.

Second, this study only adopted the reliability analysis, validity analysis, correlation analysis and regression analysis in SPSS24.0 analysis method, and the analysis process is relatively simple. In the subsequent research, we hope to try other more rigorous research methods to obtain more accurate conclusions.

\section{REFERENCES}

[1] Meng-jiao JIANG. From the communication characteristics of barrage video, the transformation of user demand of video website [D]. Jilin university, 2017.(In Chinese)

[2] Xue-qin ZHAO and Ya-ning LIU. Research on influencing factors of online video users' closing barrage [J]. News \& communication review, 2008, 7105:16-26.(In Chinese)

[3] Zhen GUO. Research on barrage video advertisement and its communication mode [J]. Journal of Beijing University of Posts and Telecommunications (social science edition), 2008, 2004:1-6.(In Chinese)

[4] Ju-Duk Yoon, Min-Ho Jang, Hyun-Bin Jo, Kwang-Seok Jeong, Gu-Yeon Kim, Gea-Jae Joo. Changes of fish assemblages after the construction of an estuary barrage in the lower Nakdong River, South Korea[J]. Limnology, 2016, 17(2)

[5] Ju-Duk Yoon, Jeong-Hui Kim, Sang-Hyeon Park, Eve Kim, Min-Ho Jang. Impact of estuary barrage construction on fish assemblages in the lower part of a river and the role of fishways as a passage[J]. Ocean Science Journal, 2017, 52(1).

[6] Herbert Jack Rotfeld. Misplaced marketing Gardening, pizza, tacos, truck parts and fake jewelry: misuse and misdirection of sex in advertising[J]. Journal of Consumer Marketing, 2003, 20(3).

[7] Narissara Parkvithee, Mario J. Miranda. The interaction effect of country-of-origin, brand equity and purchase involvement on consumer purchase intentions of clothing labels[J]. Asia Pacific Journal of Marketing and Logistics, 2012, 24(1).

[8] Oliver Koll, Sylvia von Wallpach. One brand perception? Or many? The heterogeneity of intra-brand knowledge[J]. Journal of Product \& Brand Management, 2009, 18(5)

[9] Lars Michael Wendt, Joachim Griesbaum, Ralph Kölle. Product advertising and viral stealth marketing in online videos[J]. Aslib Journal of Information Management, 2016, 68(3).

[10] Wen-bo YANG. Research on the impact of cultural uniqueness on consumers' brand attitudes under different brand perceptions [D]. Beijing foreign studies university, 2017.(In Chinese)

[11] Hong-yan LIU, and Hai-ying WEI. Influence of brand use behavior of non-target consumer groups on brand attitude of target consumers -regulating effect of self-construction [J]. Management review, 2017, 2908:110-120.(In Chinese)

[12] Deng-hua YUAN, Si-ming LUO, Chun-jiang FU, and Ying-qin XIE The influence of advertising intervention on consumers' brand attitude and trust [J]. Journal of Psychology, 2010, 4206:715-726.9.(In Chinese) 